\title{
Dynamis and Energeia in Aristotle's Metaphysics
}

\author{
Hikmet Unlu
}

Department of Philosophy, Middle East Technical University, Cankaya/Ankara, Turkey

\section{Correspondence}

Hikmet Unlu, Department of Philosophy, Middle East Technical University,

Universiteler Mahallesi, Dumlupinar Bulvari No:1, 06800 Cankaya/Ankara, Turkey.

Email: hunlu@metu.edu.tr

\begin{abstract}
This paper offers an interpretation of Aristotle's concepts of dynamis and energeia (commonly translated as potentiality and actuality) and of the thematic progression of Metaphysics IX. I first raise the question of where motion fits in Aristotle's categories and argue that the locus of motion in the system of categories are the categories of doing and suffering, in which case dynamis and energeia in respect of motion can also be understood as the dynamis and energeia of doing and suffering. Next, I argue that the analogy that Aristotle draws in IX.6 is an analogy between the dynamis and energeia of doing and suffering and the dynamis and energeia of substance. Finally, I try to show that it is this analogy between the kinetic and nonkinetic variants of dynamis and energeia-and not the distinction between endinclusive and end-exclusive activities-that provides the key to understanding the structure of Metaphysics IX.
\end{abstract}

\section{1 | INTRODUCTION}

In the Metaphysics, Aristotle states several times that being is said in many ways. According to Aristotle, being has four general senses, one of which subdivides into eight (or however many categories there are). ${ }^{1}$ The four general senses of being are (i) accidental being, (ii) being as said of the categories, (iii) being as dynamis and energeia (often translated as potentiality and actuality), and (iv) being as truth. This paper explores one of the ways in which (ii) and (iii) are related: I argue that Aristotle draws an analogy between the dynamis and energeia pertaining to the categories of doing and suffering and the dynamis and energeia pertaining to the category of substance. Because their interpretation is precisely what is at stake, I will leave the terms dynamis and energeia untranslated for the most part of this paper.

Aristotle begins Metaphysics IX with a discussion of dynamis and energeia "in respect of motion" (kata kinesin), adding immediately that there is more to dynamis and energeia than this "kinetic" sense, that "dynamis and energeia extend further (epi pleon) than the mere sphere of motion" (IX.1, 1046a1-2). ${ }^{2}$ The text therefore implies a fourfold distinction between (i) dynamis in respect of motion (dynamis kata kinēsin), (ii) energeia in respect of motion (energeia kata kinēsin), (iii) dynamis that extends further (dynamis epi pleon), and (iv) energeia that extends further (energeia epi pleon). Later in the text (IX.6, 1048a36-1048b4), Aristotle offers the following analogy: what (i) is to (ii) is what (iii) is 
to (iv). This much is agreed by most commentators. What I would like to add to this is that both the kata kinesin-epi pleon distinction in IX.1 and the analogy in IX.6 have a categorial basis.

I argue for this interpretation by discussing passages where motion is treated as a category of its own-namely, as a joint name for the categories of doing and suffering-and I suggest that this would explain why Aristotle refers to dynamis in respect of motion subsequently as the dynamis of doing and suffering. Next, I examine passages in IX.3 and XII.4-5 where the role of the categories is explicit, which passages therefore provide further support for the interpretation according to which, as Makin puts it, dynamis and energeia "apply analogously in different categories" (Makin, 2006, p. 129; emphasis in the original). Building on these insights, I try to emphasize the role of the categories in understanding the thematic progression of Metaphysics IX, in which book, I argue, Aristotle begins with the dynamis and energeia of doing and suffering and proceeds to the dynamis and energeia of substance. I argue finally that despite what has been maintained by several scholars, Aristotle's division of activities into those that are end-inclusive and those that are endexclusive does not pertain directly to the kata kinésin-epi pleon distinction in IX.1 and the analogy in IX.6. ${ }^{3}$

\section{MOTION AS DOING AND SUFFERING}

In the central books of the Metaphysics, Aristotle examines the different senses of being. Since one of the four senses of being is being as dynamis and energeia, Aristotle devotes much of Metaphysics IX to its analysis. The book begins with a discussion of dynamis and energeia "in respect of motion" (kata kinesin), but the text does not offer a clarification of this phrase. What Aristotle does tell us here is that there is more to dynamis and energeia than this "kinetic" sense, that "dynamis and energeia extend further than the mere sphere of motion" (IX.1, 1046a1-2). ${ }^{4}$ Aristotle states moreover that this kinetic type of dynamis and energeia is not the most useful, in the sense that it is not what is truly being sought (IX.1, 1045b36-1046a1). Later in the text, Aristotle offers an analogy (IX.6, 1048a36-1048b4), which shall be examined in Section 5 of the paper. Because the kata kinesin-epi pleon distinction in IX.1 and the analogy in IX.6 involve a contrast between the kinetic and nonkinetic variants of dynamis and energeia, however, we must address the question of what it means for dynamis and energeia to be kinetic.

In the Physics and the Metaphysics, Aristotle provides a definition of motion ${ }^{5}$-the entelecheia of the dynaton as such (commonly translated as "the actuality of what is potential as such")-which is a definition that applies equally to the four motions (generation/corruption, alteration, growth/diminution, and locomotion). ${ }^{6}$ For example, building is a motion that can be understood as the entelecheia of the buildable qua buildable (Physics III.1, 201a16-18). Likewise, the entelecheia of the healable as such is healing. This definition of motion has been much debated in the literature, but I will not discuss it here for the following reasons. First and foremost, the definiens consists of the very terms that I am trying to understand in the present study, so to examine the definition of motion would be, for my purposes, to put the cart before the horse. ${ }^{7}$ Second, the precise interpretation of Aristotle's definition of motion is orthogonal to the question of where motion fits in Aristotle's categories, and it is this question that the present study aims to focus on. Note, for example, that commentators sometimes debate whether Aristotle's definition of motion should be understood as the actuality of what is potential as such or as the actualization of what is potential as such, but I would like to stress that whatever the case may be, one may still raise the question concerning the locus of this actuality or actualization in the system of categories. Brentano's discussion of motion is a case in point. In his doctoral dissertation, he provides a lengthy discussion of the different ways in which one can interpret Aristotle's definition of motion (Brentano, 1975, pp. 34-48), but his later claim that motion is factually identical to the categories of doing and suffering (Brentano, 1975, p. 87) is extraneous to the aforementioned interpretations.

Where does motion fit in the system of categories? For example, a horse is a substance, a size is a quantity, and a color is a quality, ${ }^{8}$ but what about motion? On the face of it, this does not seem to be a difficult question because there are a few passages that suggest that motion is a category of its own. Granted, motion is not included in the canonical list of categories, not even in the Categories (1b26-7) and the Topics (103b22-4) where we find the most complete list of the categories. Nonetheless, there are several passages that include motion among the categories. Before proceeding further, let us take a closer look at these passages. 
In Metaphysics VII.4, Aristotle writes: "But since there are compounds of substance with the other categories (for there is a substrate for each category, e.g., for quality, quantity, time, place, and motion), we must inquire whether there is a formula of the essence of each of them" (1029b22-25). Here the inclusion of motion among the categories may seem surprising, but more surprising still is another passage where Aristotle offers a bifurcation of motion into kinein (moving) and kineisthai (being moved): "For being, as we have divided it in other works, signifies now what a thing is, now quality, now quantity, now time, and again some of it consists in kineisthai and kinein" (Eudemian Ethics 1.8, 1217b27-29). ${ }^{9}$ According to Menn, in these and several other passages, motion is the name of a category. As he puts it:

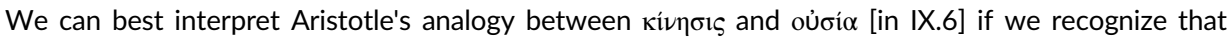

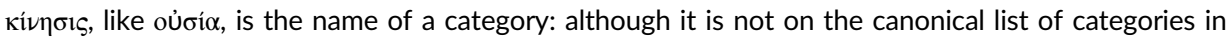
the Categories, Aristotle clearly refers to a category of kivnols in Metaphysics 1029b22-25, 1054a4-6, 1069a21-22, and 1071al-2: this is what is elsewhere divided into the categories of $\pi$ oieiv and $\pi$ á $\chi \varepsilon ı v$. (Menn, 1994, p. 107)

In his commentary on the Metaphysics, Aquinas likewise argues for the identity of kinēsis to doing and suffering: "For there is some subject of each of them, namely, of quality, quantity, when, where, and also of motion, in which are included both action and being acted upon" (Aquinas, 1995a). Elsewhere he writes, "For it is clear that both action and passion are motion; for each is the same as motion" (Aquinas, 1995b). Mention has already been made of Brentano, who maintains similarly that motion is "factually identical" to the categories of doing and suffering (Brentano, 1975, p. 87). Now, the fact (i) that there are a number of passages that count kinessis as one of the categories, (ii) that there are others that count kinein and kineisthai, and (iii) that in none of these passages, kinēsis, kinein, or kineisthai coexist with the categories of doing and suffering lend support to the line of commentary according to which kinēsis is used as a joint name for these two categories. It is important to note, moreover, that this interpretation is consistent with Aristotle's own remark that there is no motion of the poioun (doer) or the paschon (sufferer) because there is no motion of motion. As he puts it:

If the categories are classified as substance, quality, place, poiein or paschein, relation, quantity, there must be three kinds of movement-of quality, of quantity, of place. There is no movement in respect...of poioun and paschon, nor of mover and moved, because there is no movement of movement nor generation of generation, nor, in general, change of change. ${ }^{10}$ (Met. XI.12, 1068a8-16)

In what follows, I will try to show that the question concerning the locus of motion in Aristotle's categories is important for understanding the thematic progression of Metaphysics IX. More precisely, I will argue that the dynamis and energeia in respect of motion can also be understood as the dynamis and energeia of doing and suffering-or, in Aristotle's own words, dynamis tou poiein kai paschein (IX.1, 1046a19-20). First, though, I would like to interject by providing a brief exposition of the terminology traditionally adopted in discussions concerning Aristotle's concepts of dynamis, energeia, and entelecheia. ${ }^{11}$

\section{3 | THE TRADITIONAL TERMINOLOGY}

When Aristotle provides his own definition of the soul at the beginning of De Anima II.1, he draws a distinction between what appear to be different kinds of entelecheia: namely, entelecheia as the mere possession of knowledge and entelecheia as the exercise of knowledge (De Anima II.1, 412a10-11). Later in the text, Aristotle employs this distinction when providing his definition of the soul:

Now there are two kinds of entelecheia corresponding to knowledge and to the act of contemplating [i.e., the exercise of knowledge]. It is obvious that the soul is an entelecheia like knowledge; for both 
sleeping and waking presuppose the existence of soul, and of these waking corresponds to the act of contemplating, sleeping to knowledge possessed but not employed...That is why the soul is an entelecheia of the first kind of a natural body having life potentially in it. (De Anima II.1, 412a22-28)

The closing sentence of this passage features the phrase entelecheia he prōte, the likes of which are traditionally referred to as "first actuality." For example, Aquinas writes that "in Book II of The Soul [Aristotle] says that a soul is the first actuality of a natural organic body having life potentially" (Aquinas, 1995a). Elsewhere, Aquinas elaborates that "the body, complete with its soul, is potentially animate in the sense that, though it has its first actuality, it may lack the second" (Aquinas, 1994).

Those who adopt this terminology say, for example, that knowledge is the first actuality and the act of contemplating is the second or that the (sensitive) soul is the first actuality and perceiving is the second. The idea here is that first actuality is itself a potentiality for a further actuality, as a result of which first actuality may also be called second potentiality. ${ }^{12}$ For example, knowledge is an actuality, but it is at the same time a potentiality for the exercise of knowledge, the latter of which must be understood as second actuality. The person who has mastered the French language has the first actuality but does not necessarily have the second actuality, that is, unless she is uttering French sentences right now. Similarly, virtues are the first actuality, the lifelong exercise of which is happiness. Therefore, without going into the details of Aristotle's ethical theory (the question of external goods and so on), we may say that virtue is the first actuality and happiness is the second.

In other words, what is at issue is not a simple twofold division between potentiality and actuality but rather a threefold distinction between (i) first potentiality, (ii) first actuality or second potentiality, and (iii) second actuality. I think that this way of understanding the text is correct, yet there is a sense in which confining ourselves to this terminology alone may result in turning a blind eye to the categorial foundations of the kata kinesin-epi pleon distinction in IX.1 and the analogy in IX.6. One of the objectives of my interpretation, therefore, is to complement the traditional terminology, and this I try to do by emphasizing the role of the categories in the composition of Metaphysics IX. ${ }^{13}$

\section{I CAPACITY AND ACTIVITY}

Mention has been made that Aristotle begins Metaphysics IX with the fourfold distinction between (i) dynamis in respect of motion (dynamis kata kinēsin), (ii) energeia in respect of motion (energeia kata kinēsin), (iii) dynamis that extends further (dynamis epi pleon), and (iv) energeia that extends further (energeia epi pleon). Aristotle defines the first of these as "the principle of change in another thing or in the thing itself as other" (IX.1, 1046a11). ${ }^{14}$ While there are other senses of dynamis kata kinēsin, Aristotle states that it is the sense just mentioned that serves as the focal meaning. One of the other senses that depend on the focal meaning is the corresponding dynamis of the patient. The dynamis to move something else (or as something else) or be moved by something else (or as something else) is sometimes called a "power,"15 in which case Aristotle's discussion at the beginning of Metaphysics IX concerns agent and passive powers. ${ }^{16}$

In Metaphysics IX, Aristotle's first examples of agent and passive powers are the dynamis for being burned and being crushed, which are passive powers, and the dynamis for heating and building, which are agent powers. Aristotle refers to these eventually as dynameis tou poiesai $\bar{e}$ tou pathein (1046a16-17), dynamis tou poiein kai paschein (1046a19-20), and hê tou poièsai è pathein dynamis (1046b25-26), that is, the dynamis of doing and suffering. ${ }^{17}$ It is worth mentioning here that in the Categories, the examples Aristotle provides for the category of poiein are cutting and burning, and likewise the examples he gives for the category of paschein are being cut and being burned (Categories 4, 2a4). In Metaphysics IX, therefore, when Aristotle mentions the burnable (kauston) as something that has a passive capacity (IX.1, 1046a25), he is exploiting the familiar examples of burning (kaiein) and being burnt (kaiesthai). 
A point that needs to be stressed here is that there are four categories (substance, quality, quantity, and place) that are closely related to the four motions: (i) generation and corruption, (ii) alteration, (iii) growth and diminution, and (iv) locomotion (Physics III.1, 201a11-15). ${ }^{18}$ As Aristotle puts it in the Physics, "It is always with respect to (kata) substance or to quantity or to quality or to place that what changes changes" (Physics III.1, 200b33-34). Note that the categories just mentioned are those in respect of which the change occurs, and that they are therefore the categories where the effect of the motion is observed-which effect is produced by the joint activity of agent and passive powers. Let me try to demonstrate this with a couple of examples.

As has just been mentioned, cutting and being cut are the examples Aristotle gives in the Categories for poiein and paschein. Assume, for example, that I am cutting some paper (doing) and that the paper is being cut (suffering). As a result of this doing and suffering, the paper will eventually end up acquiring a new size and therefore a new quantity. In other words, after this process has been completed, the paper will have acquired a new form in the category of quantity. This kind of motion would be referred to by Aristotle as diminution (phthisis). Likewise, assume that I am painting my wall (doing) and that it is being painted by me (suffering). As a result of the joint activity of the capacities of the agent and the patient, the wall will end up acquiring a new color and therefore a new quality. This kind of motion would be referred to by Aristotle as alteration (alloiōsis). Many similar examples can be given, and what they show is that when we are dealing with motions such as building, teaching, cutting, painting, and so on, the doing and suffering take place with respect to (kata) the categories of substance, quality, quantity, or place, in which categories, moreover, the doing and suffering produce a lasting effect. But the fact that these motions take place with respect to the categories of substance, quality, quantity, or place should give us no reason to confuse motion with the categories with respect to which it takes place. It is worth noting in this context that at the end of his discussion of motion in Physics III.1-3, Aristotle describes motion as "the entelecheia of what can act and what can be acted on, as such" (Physics III.3, 202b26-27). The entelecheia of what can act as such is an action (doing), just as the entelecheia of what can be acted on as such is a passion (suffering), and it is important that we distinguish this doing and suffering from the four categories with respect to which they take place.

Let us now turn to perception. Perception is an example that Aristotle uses in two chapters (IX.3 and IX.5), both of which lie within the scope of text that by Aristotle's own admission treats dynamis in respect of motion. Why is perception treated in this part of Metaphysics IX? I argue in what follows that this is because perception, too, must be understood as the joint activity of two correlated capacities: the dynamis of the agent (the sensible object) and that of the patient (the sensing subject). If this is right, it would only be natural for Aristotle to treat perception analogously to the way in which he treats other agent and passive powers, such as cutting and being cut.

In the Physics, Aristotle writes that perception is a motion wherein the sense is affected in some respect (VII.2, 244b11-12). In the De Anima (II.12, 424a17-19), he explains perception as the reception of the sensible forms without the matter (to dektikon tōn aisthètōn eidōn aneu tēs hylès). It is precisely this "receiving" that Aristotle characterizes as a suffering when, in DA II.7-11, he provides an account of how each of the five senses relate to their particular objects. Near the end of this account (II.11, 424a1), Aristotle states in no uncertain terms that perception is a kind of suffering (to gar aisthanesthai paschein ti estin). He adds in the next chapter that plants cannot perceive precisely because they are unable to partake in this kind of suffering, namely, without the matter; plants are only capable of, as Aristotle puts it, paschein meta tēs hylēs (II.12, 424b2).

The characterization of perception as a kind of suffering is prevalent in commentaries on Aristotle's philosophy of mind. In his commentary on the De Anima (Aquinas, 1994), Aquinas maintains that perception is a kind of undergoing (sentire est pati quoddam). In the same way, Averroes states in his long commentary on the De Anima that "sensation is one of the passive powers" and even more unambiguously that "affection is the genus of sensation" (Averroes, 2009, p. 162). Likewise, Brentano writes, "We sense by being moved by the sensed object, hence by being affected" (Brentano, 1977, p. 54). Lennox points out in a similar fashion that "perception is a passive capacity, a being affected by an object of perception" (Lennox, 2001, p. 183; emphasis in the original). This view is held also by Kosman, according to whom the "perceptual capacities, and the faculties of reason and thought as well, are 
potentialities of the sensitive and intelligent subject to be affected in certain ways, to be acted upon by the sensible and intelligible forms of objects in the world" (Kosman, 2014, p. 66; emphasis in the original).

Perception is characterized specifically as an affection because it is what we do; that is to say, we (the perceiving subjects) receive the sensible forms of the objects. In the terminology of the De Anima (I.1, 402b15-16), the object (to antikeimenon) of perception is that which is sensible (to aistheton). Without going into the details of Aristotle's account of perception-for example, the role of the medium, the difference between the primary sense organ and the peripheral sense organs, the literalist vs. the spiritualist readings of Aristotle-the basic picture is that it is the sensible object that serves as the agent, which therefore has a capacity to act, just as the perceiving subject has a corresponding capacity to suffer.

In sum, once we raise the question of where motion fits in Aristotle's categories and answer that the locus of motion in the system of categories are the categories of doing and suffering, it becomes possible to understand why Aristotle's treatment of dynamis in respect of motion involves instances of dynamis tou poiein (e.g., building) and dynamis tou paschein (e.g., perceiving). But there is another issue that needs to be discussed in this context: namely, there is a sense in which each suffering (perceiving, being cut, etc.) coincides with a doing. If the wall is being painted, somebody or something is painting it. If the bricks and boards are being arranged into a house, somebody or something is arranging them so. In fact, to take Aristotle's own example in the Physics, the teaching performed by the teacher or the learning experienced by the student can be thought of as two different explanations of the same process from opposite poles. As Aristotle puts it:

Hence there is a single actuality of both [i.e., of that which can move and that which can be moved] alike, just as one to two and two to one are the same interval, and the steep ascent and the steep descent are one-for these are one and the same, although their definitions are not one....This view has a dialectical difficulty. Perhaps it is necessary that there should be [a separate] actuality of the agent and of the patient. The one is agency and the other patiency; and the outcome and end of the one is an action, that of the other a passion....[But] it is not absurd that the actualization of one thing should be in another. Teaching is the activity of a person who can teach, yet the operation is performed in something....There is nothing to prevent two things [e.g., the capacity to teach and the capacity to be taught] having one and the same actualization .... (Physics III.3, 202a18-202b9)

In his commentary on the Physics, Aquinas writes that "it is clear that action and passion are not two motions but one and the same motion" (Aquinas, 1995b), despite the fact that the two have different definitions. Ford claims likewise that "action and passion are two aspects of a single material reality, a transaction between the agent and patient" (Ford, 2014, p. 15). Gill makes a similar point: "Action and passion are one in the way that the road from Athens to Thebes and the road from Thebes to Athens are one" (Gill, 1989, p. 205).

The idea here is that to each dynamis of suffering corresponds a dynamis of doing, and even though the former dynamis is distinct from the latter, their energeia is one and the same. ${ }^{19}$ The ability to teach is not identical to the ability to be taught; what is identical, rather, is the energeia of these agent and passive powers. Similarly, the dynamis to perceive and the dynamis to be perceived are distinct, but their energeia is one and the same. In a word, dynamis in respect of motion can also be understood as the dynamis of doing and suffering, in which case energeia in respect of motion can be understood as the exercise of this kind of dynamis. In what follows, I will call dynamis in respect of motion "capacity" and energeia in respect of motion "activity." More precisely, I will call dynamis of doing or suffering "capacity" and energeia of doing or suffering "activity." 20 In the next section, I will argue that capacity and activity serve as two of the analogues in the analogy in IX.6.

\section{5 | THE ANALOGY IN METAPHYSICS IX.6}

Aristotle begins Metaphysics IX with an analysis of the kinetic versions of dynamis and energeia (i.e., capacity and activity), and these, as we shall see, serve as two of the analogues in the analogy that Aristotle introduces 
in IX.6. In other words, capacity and activity serve as the $A$ and $B$ in the analogy according to which what $A$ is to $B$ is what $C$ is to $D$. Note also, however, that Aristotle begins with agent and passive capacities because it is this kind of dynamis that he inherits from Plato. What is at issue here are on the one hand the capacity to do and on the other hand the capacity to suffer, which correspond, as the Stranger in the Sophist puts it, to the dynamis eis to poiein and the dynamis eis to pathein (247d-e). Similarly, in the Theaetetus (156a), Plato explains that there are two kinds of motion (tês de kinēseōs dyo eidê), the one having the capacity to do, the other to suffer (dynamin de to men poiein echon, to de paschein). Hence, there is enough common ground between Plato and Aristotle on this issue that one can see why Aristotle would begin his discussion of dynamis with the sense of the term that he inherits from his teacher. ${ }^{21}$

I propose that we understand the thematic progression of Metaphysics IX in the following way. Namely, Aristotle employs our understanding of agent and passive capacities, concepts that can already be found in Plato's philosophy, as a stepping stone toward an understanding of the dynamis that extends further. Of course, to each kind of dynamis corresponds a different kind of energeia. Therefore, we have, on the one hand, agent and passive capacities and their joint exercise and, on the other hand, the dynamis that extends further and its corresponding energeia. Aristotle begins IX.6 with the following words:

Since we have treated of the kind of dynamis which is related to kinesis, let us discuss energeia, what and what sort of thing it is. In the course of our analysis it will also become clear, with regard to the dynaton, that we not only ascribe dynaton to that whose nature it is to move (kinein) something else or be moved (kineisthai) by something else, either without qualification or in some particular way, but also use the word in another sense, in the pursuit of which we have discussed these previous senses. (IX.6, 1048a25-30)

It has been argued throughout this paper that the locus of motion in the system of categories are the categories of doing and suffering, which would explain why Aristotle refers to dynamis in respect of motion subsequently as dynameis tou poiēsai è tou pathein (1046a16-17), dynamis tou poiein kai paschein (1046a19-20), and hè tou poiēsai $\bar{e}$ pathein dynamis (1046b25-26). But the passage under discussion says more: we are told that the dynamis of doing and suffering is not the only dynamis; in fact, it is not the kind of dynamis that is the most useful for our purposes. What is more important for our purposes is the dynamis that extends further, but Aristotle does not provide a definition for this particular dynamis or for its corresponding energeia; instead, he explicitly asks us not to demand a definition of everything but be content to grasp the analogy. As he puts it:

[W]e must not seek a definition of everything but be content to grasp the analogy,--that as (i) that which is building is to that which is capable of building, so is (ii) the waking to the sleeping, and (iii) that which is seeing to that which has its eyes shut but has sight, and (iv) that which is shaped out of the matter to the matter, and (v) that which has been wrought to the unwrought. (IX.6, 1048a361048b4)

How should we parse out this analogy? In the light of our previous discussion, (i), (ii), and (iii) must belong together as instances of the dynamis and energeia of doing and suffering. In Metaphysics V.12, the building art (hé oikodomike dynamis) is characterized as a principle of motion (archē kinēseōs) in another (1019a15-16), so it is an agent capacity. More precisely, the capacity to build is a capacity to make (dynamis tou poiein), and it belongs to builder, just as the capacity to be built belongs to the material from which the house is made. It has already been argued, moreover, that the capacity to see-and likewise the capacity to hear, smell, taste, and touch-must be understood as a passive capacity (dynamis tou paschein) and that the agent capacity in this case belongs to the visible (or, more generally, the sensible) object. That leaves us with (ii). At the beginning of the De Somno, Aristotle writes that "waking and sleep appertain to the same part of an animal, inasmuch as they are opposites, and sleep is evidently a privation of waking" 
(453b25-26) and adds that waking "consists in nothing else than the exercise of sense-perception" (454a4-5). A few passages later, Aristotle says that "sleep is, in a certain way, or, as it were, a motionlessness bond, imposed on senseperception, while its loosening or remission constitutes the being awake" (454b25-27). In other words, waking must be understood as a releasement (lysis) into activity of the capacity for perception, which means that the relation between sleep and waking corresponds to the relation between the capacity for perception, which remains unenacted as long as the animal remains asleep, and the exercise of this capacity.

In sum, my point is that the dynamis to build or to perceive are instances of what is referred to in IX.1 as dynamis tou poiein kai paschein (IX.1, 1046a19-20), which in turn corresponds to the agent and passive capacities that we find in Plato's dialogues the Theaetetus (156a) and the Sophist (247d-e). If this is right, (i)-(iii) together comprise one side of the analogy, in which case, the other side of the analogy must consist of (iv)-(v). For similar reasons, Menn (1994, p. 106ff.) also divides the analogy into (i)-(iii) and (iv)-(v). Likewise, Makin argues that what is at issue here are "three pairs of cases framed in terms of the change-capacity relation which was the focus of $\Theta 1-5$ " and "two pairs...which concern the substance-matter relation" and adds that (i)-(iii) "illustrate the change-capacity relation," while (iv)(v) illustrate "the substance-matter relation" (Makin, 2006, p. 137). Beere, who offers a detailed analysis of the analogy (Beere, 2009, pp. 169-219), also understands the passage under discussion to draw a distinction between what he calls "the activity-like cases of energeia and the actuality-like cases of energeia" (Beere, 2009, p. 200). Elsewhere, he writes that this analogy is meant "to unify cases of doing (both changes and nonchange activities) and cases that are static" (Beere, 2018, p. 878).

I agree with much of what is said here, but I believe that more emphasis needs be placed on the categorial basis of the division of the analogy into (i)-(iii) and (iv)-(v). Again, (i)-(iii) are instances of the dynamis and energeia of doing and suffering, whereas (iv)-(v) are instances of the dynamis and energeia of substance. Some things, Aristotle concludes, "are as kinēsis to dynamis, and the others as substance to some sort of matter" (IX.6, 1048b8-9). Thus, Aristotle's remarks involve a contrast between the dynamis and energeia of motion and the dynamis and energeia of substance. ${ }^{22}$ As we shall see, another virtue of this interpretation is that it is consistent with passages in IX.3 and XII.4-5 where Aristotle talks about how the concepts of dynamis and energeia apply analogously in different categories.

\section{6 | AN INTERPRETATION OF EPI PLEON}

In the earlier sections of the paper, I tried to advance an interpretation of Metaphysics IX that places emphasis on the role of the categories. Additional support for this interpretation comes from a passage in IX.3:

Therefore it is possible that a thing may be capable of being and not be, and capable of not being and yet be, and similarly with the other kinds of predicate (epi tōn allōn katēgoriōn); it may be capable of walking and yet not walk, or capable of not walking and yet walk. (1047a20-24)

In this passage, Aristotle begins with the dynamis and energeia of substance-"a thing may be capable of being and not be"-but extends it to the other categories, and the example he gives is walking, which belongs to the category of doing. ${ }^{23}$ Here, the phrase epi tōn allōn katégoriōn (in the case of other categories) appears to be parallel to the epi pleon mentioned in IX.1, in which case "extending further" can be understood to have a categorial basis. The analogy in IX.6 begins with the categories of doing and suffering (i.e., the category of motion), so the other category is substance. The IX.3 passage, in contrast, begins with substance, so the other category is doing. What is important to realize is that similar examples are given in the aforementioned passages in IX.3 and IX.6. In the former, Aristotle begins with substance, so the explicitly mentioned allai katēgoriai include categories such as doing (e.g., walking); in the latter, Aristotle begins with the categories of doing and suffering and then proceeds to substance. If this is right, 
in IX.6, Aristotle proceeds from the dynamis and energeia of motion to the dynamis and energeia of substance, whereas in IX.3, he proceeds from the dynamis and energeia of substance to the dynamis and energeia of motion.

Another advantage of this interpretation is that it agrees with various passages in Metaphysics XII.4-5, which also discuss, as Makin puts it, how dynamis and energeia "apply analogously in the different categories" (Makin, 2006, p. 129; emphasis in the original). In one of these passages Aristotle writes the following:

The causes and the principles of different things are in a sense different, but in a sense, if one speaks universally and analogically, they are the same for all. For we might raise the question whether the principles and elements are different or the same for substances and for relatives, and similarly in the case of each of the categories. (XII.4, 1070a31-35)

In this passage, Aristotle mentions neither dynamis nor energeia, but in the next chapter, he adds that "analogically identical things are principles, that is, energeia and dynamis" (XII.5, 1071a4-5). I agree with Makin that, taken together, these passages suggest that dynamis and energeia apply analogously in different categories. What can we conclude from these? If we understand the distinction between the kinetic and nonkinetic variants of dynamis and energeia in IX.1 in categorial terms, and if we likewise grant that the analogy in IX.6 has a categorial basis, our interpretation would be in line with passages in IX.3 and XII.4-5, in which passages, Aristotle explicitly mentions the categories when talking about the (analogical) extension of dynamis and energeia. ${ }^{24}$

This leaves us with one more point to be discussed, which is the distinction that Aristotle draws in Metaphysics IX.6 and Nicomachean Ethics X.4 between end-inclusive and end-exclusive activities. My goal will be to show that this distinction is not pertinent to the thematic progression of Metaphysics IX.

\section{7 | THE ENERGEIA-KINĒSIS DISTINCTION}

In this last section, I will critically examine the claim that Aristotle's division of activities into those that are endinclusive and those that are end-exclusive pertains directly to the thematic progression of Metaphysics IX. I will have to say three things about this position. First, I will argue that it is incompatible with the categorial interpretation of the analogy in IX.6, an interpretation for which we have strong evidence. Next, I will point out that because the manuscript evidence for the IX.6 passage containing the energeia-kinessis distinction is weak, it would be wrong to rely too much on this passage in interpreting Metaphysics IX. Finally, I will try to draw insights from Aristotle's discussion of perception and argue that perception is an end-inclusive activity that would not have been treated in IX.1-5 if these chapters were confined to a discussion of end-exclusive activities.

Let us first try to understand what is meant by the energeia-kinessis distinction. In the Nicomachean Ethics, in a passage where he tries to determine the ontological status of pleasure, Aristotle writes the following:

For every motion (e.g., that of building) takes time and is for the sake of an end, and is complete when it has made what it aims at. It is complete, therefore, only in the whole time or at the final moment. In their parts and during the time they occupy, all motions are incomplete...So, too, in the case walking and all other motions. (Nicomachean Ethics X.4, 1174a29)

These remarks suggest that as long as somebody is walking, the telos has not been reached yet, which is another way of saying that each and every part of walking is necessarily ateles. ${ }^{25}$ What is important about these activities is that they have their ends outside themselves. For example, being in Athens is the end of walking toward Athens, but the two cannot co-exist: I cannot be walking toward Athens if I am already in it, just as it cannot be the case that I am in Athens as long as I am walking toward the city. The goal of walking toward Athens, in fact, is to no longer be walking towards Athens, which is why all such activities have what Kosman calls a "self-destructive character" 
(Kosman, 1969, p. 58). In Metaphysics IX.6, Aristotle distinguishes these activities from activities that are at each moment complete:

E.g. at the same time we are seeing and have seen, are understanding and have understood, are thinking and have thought: but it is not true that at the same time we are learning and have learnt, or are being cured and have been cured...Of these, then, we must call the one set kineseis, and the other energeiai. (1048b23-28)

Commenting on the relation of energeia to kinēsis, Ross draws attention to terminological inconsistencies in Aristotle; according to Ross, Aristotle uses the same name for the genus (characterized alternatively as kinesis or energeia) and the two species of the genus. ${ }^{26}$ Menn argues, rather, that energeia is the genus, while complete and incomplete

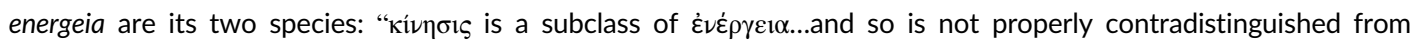

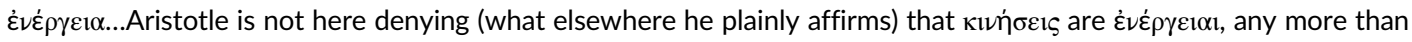
I deny that men are animals when I say 'this kind of thing I call an animal, that a man'” (Menn, 1994, p. 106, n. 43). ${ }^{27}$ In Menn's example, animal is the genus, while rational and irrational animal are its species, and in the above passage, the two species of the genus energeia are complete and incomplete energeia. Sometimes, we distinguish man from animal, in which case, we are not denying that man is, properly speaking, a distinct kind of animal; what we mean to say is that man is different from other animals, namely, from those that are irrational. Despite their differences, Ross, Menn, and Beere share the view that what is at issue here are (i) a genus and (ii) different species of the genus. Despite terminological inconsistencies in Aristotle, then, these commentators agree that there is a certain genus, whose species can be distinguished from one another by some differentia.

The basic idea behind the energeia-kinēsis distinction is that some activities have their ends within (e.g., seeing, understanding, thinking, living well, being happy), while others do not (e.g., making thin, learning, being cured, walking, building). And there is a way to tell the one kind of activities from the other. The question Aristotle wants us to consider is whether the present tense of these verbs implies the perfect tense. For example, does somebody who is seeing imply a person who has seen? Does somebody who is learning imply a person who has learned? In the former case, yes, in the latter, no.

On one common interpretation of the energeia-kinèsis distinction, the present does not imply the perfect in cases where what is at issue is an activity the completion of which requires time. ${ }^{28}$ As Halper puts it, end-inclusive activities "are timeless in the sense that their definitions need not include time" (Halper, 1989, p. 209). In other words, unlike walking from Thebes to Athens, which takes time to complete (and when the journey is complete, the walking will have ceased), seeing red is at each moment complete. According to Kosman, it is because an end-inclusive activity "does not need to await any further development to perfect or complete its being that it is complete and perfect at each and every present moment of its duration" ( Kosman, 2013). If I am seeing red, this entails, in Aristotle's view, that I have seen red; that is, nobody can claim that I have not seen red if I am seeing it right now. In other words, seeing red has at each moment its telos within; it is at each moment entelés.

There have been commentators who maintain, for various reasons, that the division of activities into those that are end-inclusive and those that are end-exclusive pertains directly to the thematic progression of Metaphysics IX. ${ }^{29}$ Other commentators disagree with this view, and I believe they are right. Let us remember Aristotle's analogy in IX.6:

[A]s (i) that which is building is to that which is capable of building, so is (ii) the waking to the sleeping, and (iii) that which is seeing to that which has its eyes shut but has sight, and (iv) that which is shaped out of the matter to the matter, and $(v)$ that which has been wrought to the unwrought. (IX.6, 1048a37-1048b4)

If this analogy were structured in terms of the energeia-kinēsis distinction, we should not expect (i)-(iii) to belong together, for (i) exemplifies an end-exclusive activity (because to build does not entail to have built), whereas (ii) and (iii)-or at least (iii), which is unambiguous-exemplify end-inclusive activities (because to perceive entails to have perceived). This would 
explain why commentators have maintained that (i)-(iii) do not belong together (Halper, 1989, p. 209) or that (i)-(iii) do not initially seem to belong together (Gill, 1989, p. 215). ${ }^{30}$ This way of understanding the text, according to which the unity of (i)-(iii) is either denied or believed to be a complex issue, is therefore incompatible with the categorial interpretation of the analogy, for on this interpretation there are no grounds to doubt the unity of (i)-(iii) because they all concern the same categories, namely, the categories of doing and suffering. In Section 5 of the paper, I explained that (i)-(iii) must belong together because building, waking, and seeing all fall under the categories of doing and suffering, the dynamis and energeia of which Aristotle means to compare with the dynamis and energeia of substance.

The categorial interpretation of the analogy that I advanced in this paper is in line with the view held not only by commentators according to whom the energeia-kinēsis distinction does not belong in the text of IX.6 (more on this shortly) but also by commentators according to whom the energeia-kinessis distinction is a finer distinction that is not directly pertinent to the analogy. According to Makin, for example, what is at issue in (i)-(iii) is an "undifferentiated notion of change" (Makin, 2006, p. 134). Makin adds in the next lines that Aristotle's "conclusions [in IX.1-5] concerning capacities and their exercise will not be sensitive to the more fine-grained distinction" between end-inclusive and end-exclusive activities (Makin, 2006, p. 135), and he concludes eventually that "the 1048b18-35 distinction between change and actuality is not crucial to Met. $\Theta$ " (Makin, 2006, p. 154). For similar reasons, Witt argues that if "one makes the distinction between motions and activities crucial [here]...then it is very difficult to interpret [Aristotle's] examples, which include both motions like building and activities like seeing" (Witt, 2003, p. 134, n. 20).

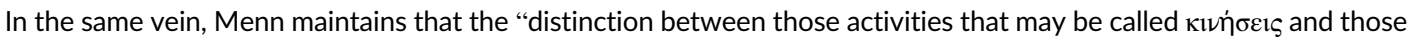

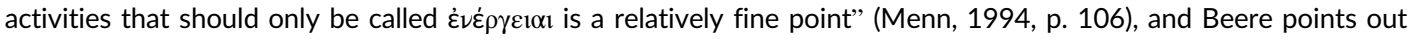
likewise that he "does not accept [the] interpretation" that "the distinction between change and energeia is important in Theta 6" (Beere, 2009, p. 228). In sum, I agree with the conclusions reached by these commentators (who appeal to Aristotle's examples as evidence that the energeia-kinessis distinction is a finer distinction that is not directly pertinent to the analogy in IX.6) because, once again, the interpretation of the analogy that has been advanced in this paper is one that distinguishes sharply between (i)-(iii) and (iv)-(v), which distinction has a categorial basis.

Furthermore, it is important to keep in mind that the manuscript evidence for the IX.6 passage containing the energeia-kinessis distinction is weak. ${ }^{31}$ This is not to suggest that Aristotle never draws such a distinction; mention has been made that Aristotle draws a similar distinction in Nicomachean Ethics X.4. Note, however, that one may believe that the distinction between end-inclusive and end-exclusive activities is an Aristotelian distinction and still question its inclusion in IX.6. For example, Halper, according to whom the distinction is significant for the composition of Metaphysics IX, concedes nevertheless that the passage in question is one that is "absent from the best manuscripts" (Halper, 1989, p. 209). Likewise, Kosman concedes the "high probability that the passage is an interloper" but adds that this "raises little difficulty" for his position (Kosman, 2013). Granted, even if the passage has been inserted by an editor, this would not show that the distinction is not an Aristotelian distinction or even that it is an insignificant distinction, but such a concession would take away from the original appeal of attempts to treat the energeia-kinesis distinction as the key to understanding the structure of Metaphysics IX. In sum, the manuscript status of the passage containing the energeia-kinēsis distinction cannot be taken as conclusive evidence for a particular way of reading the text, but it should at least caution us against relying too much on this passage in our interpretations of Metaphysics IX.

Finally, and I think most importantly, those who hold the view that Aristotle's division of activities into those that are end-inclusive and those that are end-exclusive is significant for the composition of Metaphysics IX will have a difficult time explaining why perception, which is an end-inclusive activity that happens to be one of the analogues in the analogy, is mentioned twice in IX.1-5. In IX.3, for example, whether the capacity for perception exists when it is not being enacted and likewise whether sensible qualities exist when they are not being perceived are some of the central questions in Aristotle's confrontation with the Megarian philosophers. Perception is also mentioned at the very beginning of IX.5, which is generally believed to serve as a summary of the earlier chapters. The point that I wish to make here is the following: insofar as IX.1-5 does not include a discussion of the epi pleon variant of $d y n a m i s$, the capacity to perceive must be kinetic. But if the kinetic variant of dynamis were to be interpreted as the dynamis 
pertaining to end-exclusive activities, which some believe is the correct interpretation, perception too would have to count as an end-exclusive activity. Quite the contrary, however, it is clear that Aristotle considers perception to be an end-inclusive activity (De Sensu 6, 446b2-3; Metaphysics IX.6, 1048b23; IX.6, 1048b33-34). There is a problem here, then, and the problem has to do with the interpretation of the kinetic version of dynamis as the dynamis pertaining to end-exclusive activities. The categorial interpretation of dynamis kata kinesin is not plagued by this problem because it would not be surprising for Aristotle to include a discussion of perception here if the kind of dynamis treated in IX.1-5 is the dynamis of doing and suffering and if perception is a suffering, as I have argued is the case.

On a final note, most commentators agree that there are terminological inconsistencies on the part of Aristotle, and I think that this is because Aristotle uses two terms to refer to three concepts. To distinguish clearly between these concepts, I call the genus "activity" (a concept which I described as the joint exercise of correlative agent and passive capacities), while I call its species "end-inclusive activity" and "end-exclusive activity," Among these, the term energeia refers sometimes to activity in general and sometimes to end-inclusive activity. ${ }^{32}$ The term kinesis refers to end-exclusive activity, but if the arguments in this paper have been successful, it also refers to activity in general, which is in line with the terminology adopted by Makin, who talks about an "undifferentiated notion of change" (Makin, 2006, p. 134) that includes building and seeing, and likewise with the terminology adopted by Witt, who divides motion into "incomplete and complete motions" (Witt, 2003, p. 50). If kinésis were confined to end-exclusive activity, we would not be able to explain why kinessis is sometimes listed as a category (because not everything belonging under this category is end-exclusive) and why the capacity for perception, which is an instance of endinclusive activity, is treated among the kinetic variants of dynamis. I am therefore in complete agreement with Ross,

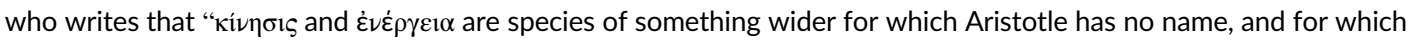
he uses now the name of one species, now that of the other" (Ross (1924, Vol. 2, p. 251). ${ }^{33}$ What I would add to this is that the more specific difference between the two species of the genus (i.e., the difference between the endinclusive and end-exclusive species) is not pertinent to the composition of Metaphysics IX.

To facilitate further discussion of these issues, let me restate the conclusions of this paper as clearly as possible: (i) the locus of motion in Aristotle's categories are the categories of doing and suffering, (ii) dynamis and energeia in respect of motion can also be understood as the dynamis and energeia of doing and suffering, (iii) Metaphysics IX begins with a discussion of the dynamis and energeia of doing and suffering and proceeds to a discussion of the dynamis and energeia of substance, and (iv) Aristotle's distinction between end-inclusive and end-exclusive activities does not pertain directly to the thematic progression of Metaphysics IX.

\section{ORCID}

Hikmet Unlu (D) https://orcid.org/0000-0003-1391-8059

\section{ENDNOTES}

${ }^{1}$ The clearest formulation of the fourfold division is in VI.2, 1026a33-1026b2, of the eightfold division in V.7, 1017a25-7. Note that while the latter is the most comprehensive list of the categories in the Metaphysics, the passages in Categories 4, 1b26-7 and Topics 1.9, 103b22-4 also include keisthai and echein, in which case we end up with 10 categories instead of eight.

${ }^{2}$ For translations of Aristotle I follow Barnes (ed.), The Complete Works of Aristotle: The Revised Oxford Translation, sometimes with slight modifications.

${ }^{3}$ I owe this terminology (end-inclusive vs. end-exclusive) to Charles (2018), who in turn cites Alexander Mourelatos.

${ }^{4}$ Aristotle points out in Metaphysics IX.1, 1045b35-1046a1 that he will first treat the kind of dynamis that is less useful for our present purposes and in IX.6, 1048a25-26 that the foregoing discussion has treated dynamis in respect of motion. While these remarks give the impression that IX.1-5 is confined to a discussion of dynamis and that later chapters will focus on energeia (I thank an anonymous reviewer for pointing this out), this way of understanding the composition of Metaphysics IX has more drawbacks than advantages, for it then becomes very difficult to explain the text of IX.3 and

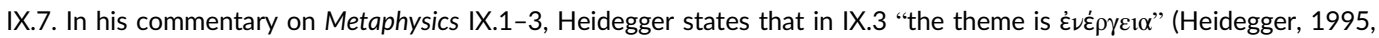
p. 148), and while this is not entirely clear, it would be very difficult to maintain that this chapter treats energeia only to 
clarify the concept of dynamis because at the end of the chapter dynamis is not even a part of the discussion (IX.3, 1047a30-1047b2), which discussion rather examines the origins of the concept of energeia and, moreover, the relationship between energeia and entelecheia. Makin maintains likewise that the second part of the chapter comments on energeia (Makin, 2006, p. 60), which would not be surprising because in earlier passages in the chapter Aristotle has argued (against the Megarian philosophers) that dynamis in respect of motion and energeia in respect of motion are two separate concepts that should not be conflated. Furthermore, the discussion of dynamis cannot be confined to IX.1-5, for dynamis becomes the theme also in IX.7. As Beere puts it, "In Theta 7, Aristotle shifts the focus of his discussion from being-in-energeia to being-in-capacity" (Beere, 2009, p. 231), and Witt writes likewise that IX.7 is concerned with the "question about potentiality, which is how to determine when one thing is another potentially" (Witt, 2003, p. 133, n. 14). There are reasons to believe, therefore, that IX.1-5 includes a discussion of energeia, just as later chapters include a discussion of dynamis.

${ }^{5}$ Various formulations of the definition can be found in Physics III.1-3 and in Metaphysics XI.9.

${ }^{6}$ See especially Physics III.1, 201a11-15. If motion is from contrary to contrary, however, there can only be three motions (see fn. 14 below for further discussion).

7 See also Kosman (2013, pp. 70-71).

${ }^{8}$ See Categories 4 for the examples Aristotle gives to each category.

9 Note that the bifurcation of kinēsis into kinein (moving) and kineisthai (being moved) also occurs in Metaphysics IX.6, where Aristotle mentions kinēsis in 1048a25 and kinein and kineisthai in 1048a28-29.

${ }^{10}$ Commenting on this passage, Aquinas argues that there cannot be a motion of doing or suffering because doing and suffering are already motion (agere et pati sunt motus) and there cannot be a motion of motion (Aquinas, 1995a).

11 The relation between the terms energeia and entelecheia is too large a topic to explore here, so the reader is referred to

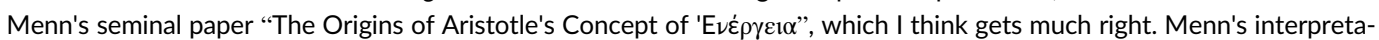
tion has been challenged by Blair (1995) and Graham (1995). See Olshewsky (1997, pp. 1-4) for an overview of different interpretations.

12 As Edward Halper puts it, "The first actuality...is a potentiality that can be actualized further, such as knowledge that is not in use. A first actuality is potentially a second actuality, and is thus both potential and actual" (Halper, 1989, p. 164). Likewise, Kosman writes that "a first actuality is a potentiality toward a second actuality" (Kosman, 1969, p. 51). Cf. Ross (1936, p. 88).

${ }^{13}$ Commentators who adopt the traditional terminology agree minimally that Aristotle intends to distinguish between first potentiality, first actuality (or second potentiality), and second actuality. An interpretation of Metaphysics IX that emphasizes the role of the categories is not incompatible with this minimal agreement. See also fn. 20 below.

${ }^{14}$ For the most part Aristotle uses the terms change and motion interchangeably, but there is a well-known exception in Physics V.1, where Aristotle draws a distinction between the two terms, arguing that since motion (kinesis) is from contrary to contrary, there are four changes (metabolai) but only three motions (225b8-9, see also Metaphysics XI.12, 1068a9-10), in which case neither generation nor corruption would count as an instance of motion. In most other passages, however, the terms kinèsis and metabolē and the phrases archē kinēseōs and archè metabolès alternate without any sign of a distinction in meaning.

15 See also Beere (2009, pp. 33-67) on his use of the term “power." Cf. Halper (1989, pp. 286-287, n. 2) and Graham (1995, p. 558ff.).

${ }^{16}$ Witt writes that she prefers to "use the terminology agent and passive powers, instead of active and passive powers, in order to avoid confusing this distinction with the other important contrast Aristotle draws between inactive and active powers" (Witt, 2003, p. 132, n. 9). I adopt Witt's terminology because I share the same concerns.

17 In two of these passages, Aristotle also talks about doing and suffering well, which are simply more specific kinds of doing and suffering.

18 See also Categories 14, 15a13-14, De Anima I.3, 406a12-13, and Metaphysics XII.2, 1069b9-10. In the last passage, the connection between the four categories (substance, quality, quantity, place) and the four motions (generation/corruption, alteration, growth/diminution, locomotion) is made explicit.

19 Here one may raise the following question: why are doing and suffering treated as two different categories if, in fact, they are simply two ways of explaining the same activity from different perspectives? While this question is too complex to discuss adequately here, an excellent discussion of the subject can be found in Brentano (1975, pp. 86-89).

20 Note that the way that I use the term "activity" would correspond to the "second actuality" of the traditional terminology. My point is that the locus of this kind of energeia (i.e., the exercise of a capacity) are the categories of doing and suffering. In my view, the energeia of substance is not a second actuality, and I believe that it is a first actuality, but I also 
believe that first actualities are not confined to the energeia of substance. These are difficult issues that cannot be treated in passing, however, so I will not discuss them further here.

21 See also Beere (2009, pp.3-29) and Menn (1994, p. 74).

22 Part of this interpretation-namely, that there are on the one hand the dynamis and energeia of motion and on the other hand the dynamis and energeia of substance-is already commonly held. However, few scholars have emphasized the role of the categories in their interpretations of the kata kinesin-epi pleon distinction in IX.1 and of Aristotle's analogy in IX.6. Menn mentions their role (Menn, 1994, p. 95, n. 32 and pp. 105-107), but only in passing. Similarly, Averroes, in his "epitome" commentary on the Metaphysics, briefly mentions the categorial basis of Aristotle's analogy in IX.6, but he interprets the analogy in a different way (Averroes, 2010, p. 99).

23 In Metaphysics IX, Aristotle discusses the relation between the capacity for doing or suffering and the capacity for doing or suffering well (IX.1, 1046a17; IX.2, 1946b25). An analogue of this discussion can be found in Metaphysics V.12, where Aristotle talks about the difference between walking and walking well (1019a24-26) and adds in the next sentence that the same holds for paschein, from which we can gather that the capacity to walk is a dynamis tou poiein.

${ }^{24}$ Note that there is an important extent to which my understanding of Metaphysics IX is not incompatible with the interpretation of the book advanced by Witt, who argues that Aristotle illustrates the relationship between dynamis and energeia "with two kinds of examples: the relationship between an inactive capacity and its active exercise, and the relationship between an incomplete substance and a complete (or perfected) substance" (Witt, 2003, p. 39). To acknowledge, as I do, that there is "one" concept of dynamis and "one" concept of energeia that apply analogically in different categories is to acknowledge what Witt would call the "ontological" sense of these terms, in which case Witt's interpretation of the text is not much different from mine, at least in this respect. Similarly, I would not disagree with Frede, according to whom the dynamis and energeia treated in IX.6-7 is not "a further, distinct kind" of dynamis (Frede, 1994, p. 180) or "a distinct, special kind" of energeia (Frede, 1994, p. 182) over and above those already treated in IX.1-5. The point that I have been trying to make is that there is an analogical extension of these concepts in different categories, in which case I am in no way denying that the analogues enjoy some kind of unity. I discuss this issue in a recent paper, where I address the question of what ties together the kinetic and non-kinetic variants of dynamis and energeia (Unlu, 2020, pp. 135-138).

25 According to Kosman, walking in the sense of strolling (spazieren) counts as an end-inclusive activity (Kosman, 1969, p. 58), but it should give us pause that this is not Aristotle's own example. For further discussion of this example, see Carter (2014, p. 476ff). Cf. Ackrill (1965, pp. 131-133).

26 See Ross (1924, Vol. 2, p. 251). Halper talks about similar terminological inconsistencies (Halper, 1989, p. 283, n. 206).

27 Beere holds a similar view (Beere, 2009, p. 229).

${ }^{28}$ Aristotle maintains that every motion (kinēsis), as opposed to energeia proper, takes time (Nicomachean Ethics X.4, 1174a19).

29 For example, Halper introduces the energeia-kinesis distinction with the following words: "Since Aristotle defines actuality through this analogy with motion, and since it and the potentiality for it differ from motion and the potentiality for motion, the analogy calls for a distinction between motion and actuality" (Halper, 1989, p. 209). See also Halper (1984, pp. 815-818); Kosman (1984); Gill (1989, pp. 214-218); and Kosman (2013, pp. 73-78).

30 Gill tries nevertheless to preserve the unity of (i)-(iii) by suggesting that building is not a motion (Gill, 1989, pp. 224-225). See also Kosman (2013, p. 264, n. 5) and the containing paragraph. My own view is that it is a forced interpretation to use the very distinction by which Aristotle distinguishes building from seeing to argue somehow that building and seeing belong together.

31 See Makin (2006, p. 150), Burnyeat (2008), and Beere (2009, pp. 226-227) for a detailed discussion of the manuscript evidence for the passage on the energeia-kinēsis distinction.

32 Kosman writes similarly that an activity is either "an activity proper or a motion" (Kosman, 2013, p. 71). On another note, it is important to keep in mind that the term energeia also refers to energeia epi pleon, which is, however, outside of the genus that we are interested in presently. Yet, it is precisely this fact-that is, that there is an epi pleon version of energeia-that explains why Aristotle treats kinesis as the paradigmatic energeia. According to Kosman, "If motion is a degenerate kind of $\dot{\varepsilon} \nu \dot{\varepsilon} \rho \gamma \varepsilon 1 \alpha$, it is not clear why Aristotle should have thought it an (even putative) paradigm of $\dot{\varepsilon} \nu \dot{\varepsilon} \rho \gamma \varepsilon 1 \alpha . "$ (Kosman, 1969, p. 59). I think that the interpretation advanced in this paper resolves this difficulty: there is both a kinetic and a non-kinetic version of energeia, and it is the former of these-that is, energeia in the sense of activity-that serves as the paradigm.

33 Note that unlike Kosman, who divides activity into activity proper and motion (Kosman, 2013, p. 71), Witt divides motion into "incomplete and complete motions" (Kosman, 2013, p. 50), but despite the different terminology, the basic idea is the same. 


\section{REFERENCES}

Ackrill, J. L. (1965). Aristotle's distinction between Energeia and Kinesis. In R. Bambrough (Ed.), New essays on Plato and Aristotle (pp. 121-141). London, England: Routledge \& Kegan Paul.

Aquinas, T. (1994). Sentencia libri De anima. Translated by K. Foster and S. Humphries. Notre Dame, IN: Dumb Ox Books.

Aquinas, T. (1995a). In duodecim Libros Metaphysicorum Aristotelis expositio. Translated by J. P. Rowan. Notre Dame, IN: Dumb Ox Books.

Aquinas, T. (1995b). In octo Libros Physicorum Aristotelis expositio. Translated by R. J. Blackwell, R. J. Spath, and E. Thirlkel. Notre Dame, IN: Dumb Ox Books.

Averroes. (2009). Long commentary on the De Anima of Aristotle. Translated by R. C. Taylor. New Haven, CT and London, England: Yale University Press.

Averroes. (2010). On Aristotle's "Metaphysics": An annotated translation of the so-called "Epitome”. Translated by R. D. Arnzen. Berlin, Germany: De Gruyter.

Beere, J. (2009). Doing and being: An interpretation of Aristotle's metaphysics theta. New York, NY: Oxford University Press.

Beere, J. (2018). Activity, actuality, and analogy: Comments on Aryeh Kosman, The Activity of Being: An Essay on Aristotle's Ontology. European Journal of Philosophy, 26(2), 872-880.

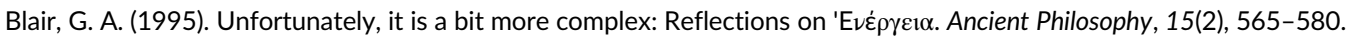

Brentano, F. (1975). On the several senses of being in Aristotle. Translated by Rolf George. Berkeley, CA: University of California Press.

Brentano, F. (1977). The psychology of Aristotle: In particular his doctrine of the active intellect. Translated by Rolf George. Berkeley, CA: University of California Press.

Burnyeat, M. (2008). Kinēsis vs. Energeia: A much-read passage in (but not of) Aristotle's Metaphysics. Oxford Studies in Ancient Philosophy, 34, 219-292.

Carter, J. P. (2014). Heidegger's Sein zum Tode as radicalization of Aristotle's definition of Kinēsis. Epoché, 18(2), 473-502.

Charles, D. (2018). Comments on Aryeh Kosman's The Activity of Being: An Essay on Aristotle's Ontology. European Journal of Philosophy, 26(2), 860-871.

Ford, A. (2014). Action and passion. Philosophical Topics, 42(1), 13-42.

Frede, M. (1994). Aristotle's notion of potentiality in Metaphysics $\Theta$. In T. Scaltsas, D. Charles, \& M. L. Gill (Eds.), Unity, identity, and explanation in Aristotle's Metaphysics (pp. 173-193). Oxford, England: Clarendon Press.

Gill, M. L. (1989). Aristotle on substance: The paradox of Unity. Princeton, NJ: Princeton University Press.

Graham, D. W. (1995). The development of Aristotle's concept of actuality: Comments on a reconstruction by Stephen Menn. Ancient Philosophy, 15(2), 551-564.

Halper, E. C. (1984). Aristotle on knowledge of nature. The Review of Metaphysics, 37(4), 811-835.

Halper, E. C. (1989). One and many in Aristotle's Metaphysics: The central books. Columbus, OH: Ohio State University Press.

Heidegger, M. (1995). Aristotle's Metaphysics $\Theta$ 1-3: On the essence and actuality of force. Translated by Walter Brogan and Peter Warnek. Bloomington, IN: Indiana University Press.

Kosman, L. A. (1969). Aristotle's definition of motion. Phronesis, 14(1), 40-62.

Kosman, L. A. (1984). Substance, Being, and Energeia. Oxford Studies in Ancient Philosophy, 2, 121-149.

Kosman, L. A. (2013). The Activity of Being: An Essay on Aristotle's Ontology. Cambridge, MA: Harvard University Press.

Kosman, L. A. (2014). Being properly affected: Virtues and feelings in Aristotle's ethics. In Virtues of thought: Essays on Plato and Aristotle (pp. 62-76). Cambridge, MA: Harvard University Press.

Lennox, J. G. (2001). Aristotle: On the parts of animals I-IV. Oxford, England: The Clarendon Press.

Makin, S. (2006). Aristotle: Metaphysics book $\Theta$. New York, NY: Oxford University Press.

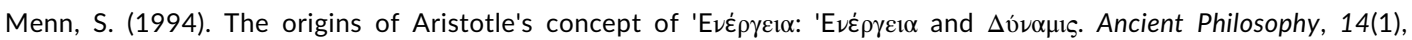
73-114.

Olshewsky, T. (1997, December). Energeia and Entelecheia: Their conception, development and relation. The Society for Ancient Greek Philosophy Newsletter. Paper presented at the SAGP Meeting for the American Philological Association, Chicago, IL.

Ross, W. D. (1924). Aristotle's Metaphysics: A revised text with Introduction and commentary (Vol. 2). Oxford, England: The Clarendon Press.

Ross, W. D. (1936). Aristotle's physics: A revised text with Introduction and commentary. Oxford, England: The Clarendon Press. Unlu, H. (2020). Aristotle, Heidegger, and the Megarians. Revue Roumaine de Philosophie, 64(1), 125-140.

Witt, C. (2003). Ways of being: Potentiality and actuality in Aristotle's Metaphysics. Ithaca, NY: Cornell University Press.

How to cite this article: Unlu H. Dynamis and Energeia in Aristotle's Metaphysics. Eur J Philos. 2022;30:17-31.

https://doi.org/10.1111/ejop.12635 